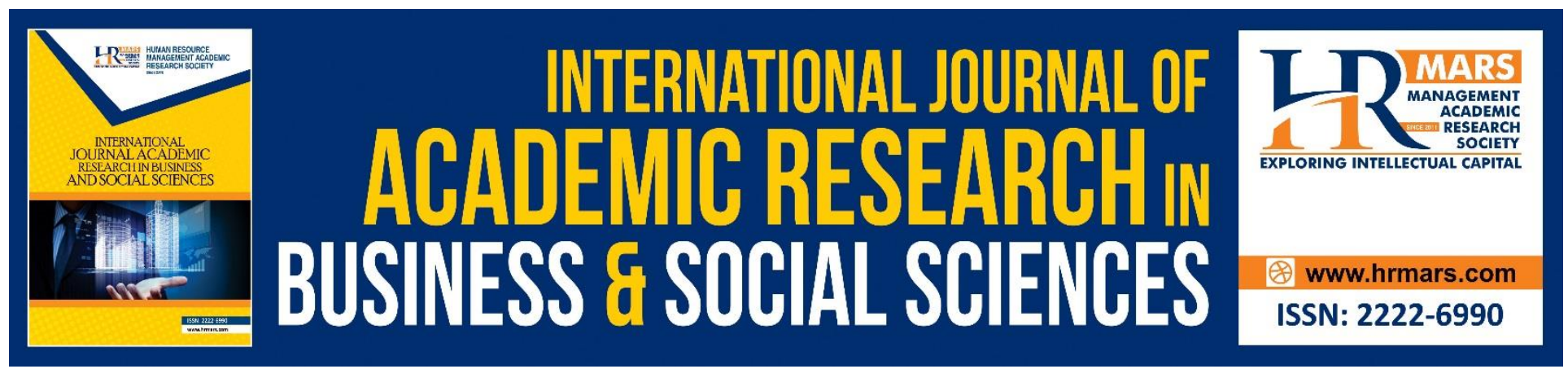

\title{
Universal Moral Values in Arabic Language Structure: A Concept, Component and Meaning
}

Mohd Nizwan Musling, Muhammad Zahid Ismail, Mohd Rosmizi Abd Rahman, Robiatul Adawiyah Mohd @ Amat

To Link this Article: http://dx.doi.org/10.6007/IJARBSS/v10-i7/7616

DOI:10.6007/IJARBSS/v10-i7/7616

Received: 05 May 2020, Revised: 08 June 2020, Accepted: 21 July 2020

Published Online: 27 July 2020

In-Text Citation: (Musling et al., 2020)

To Cite this Article: Musling, M. N., Ismail, M. Z., Rahman, M. R. A., \& Amat, R. A. M. @. (2020). Universal Moral Values in Arabic Language Structure: A Concept, Component and Meaning. International Journal of Academic Research in Business and Social Sciences, 10(7), 852-868.

Copyright: (C) 2020 The Author(s)

Published by Human Resource Management Academic Research Society (www.hrmars.com)

This article is published under the Creative Commons Attribution (CC BY 4.0) license. Anyone may reproduce, distribute, translate and create derivative works of this article (for both commercial and non-commercial purposes), subject to full attribution to the original publication and authors. The full terms of this license may be seen at: http://creativecommons.org/licences/by/4.0/legalcode

Vol. 10, No. 7, 2020, Pg. 852 - 868

Full Terms \& Conditions of access and use can be found at http://hrmars.com/index.php/pages/detail/publication-ethics 


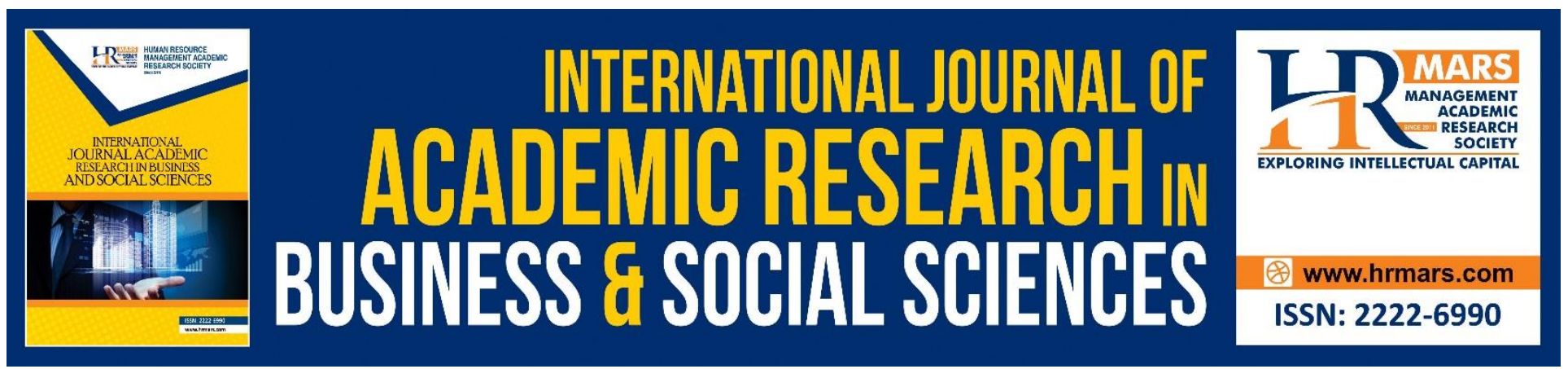

\title{
Universal Moral Values in Arabic Language Structure: A Concept, Component and Meaning
}

\section{Mohd Nizwan Musling ${ }^{1}$, Muhammad Zahid Ismail², Mohd Rosmizi Abd Rahman ${ }^{3}$, Robiatul Adawiyah Mohd @ Amat ${ }^{4}$}

${ }^{1}$ Faculty of Major Language Studies, Universiti Sains Islam Malaysia, Bandar Baru Nilai, 71800 Nilai, Negeri Sembilan, Malaysia, ${ }^{2}$ Islamic Science Institute, Universiti Sains Islam Malaysia, Bandar Baru Nilai, 71800 Nilai, Negeri Sembilan, Malaysia ${ }^{3}$ Faculty of Leadership and Management, Universiti Sains Islam Malaysia, Bandar Baru Nilai, 71800 Nilai, Negeri Sembilan, Malaysia, ${ }^{4}$ Faculty of Quranic and Sunnah Studies, Universiti Sains Islam Malaysia, Bandar Baru Nilai, 71800 Nilai, Negeri Sembilan, Malaysia.

\begin{abstract}
The importance of moral values in the development of mankind has attracted the attention of researchers from various fields. However, moral values are often considered to be subjective. Therefore, this research will attempt to explore the universal concept of moral values that may be expressed through language structures. The qualitative approach is used to achieve the main objective of the research, choosing the analysis content method in the extraction of data through online databases and other related studies. The findings show that universal moral values (UMV) are based on shared basic code of principles or common beliefs held by people across all religion, socio-cultural and nation. Altogether, there are 86 components of UMV which are categorized under 4 interrelated clusters namely 1 ) the commitment to comply to an entity higher than oneself, 2) pure personality in terms of maintaining self-respect, discipline and responsibility, 3) Respecting and loving others, 4) caring for other living things and the environment All of these four clusters can be revealed through the Arab language structure via the analysis of morphemes as well as sentences that carry the above messages.
\end{abstract}

Keywords: Universal Moral Values, Arabic Language Structure, Component, Cognitive, Behaviour.

\section{Introduction}

Values, as one of humanity's natural characteristic, have attracted the attention of scholars from various fields such as education, management, psychology, anthropology, cognitive neuroscience and linguistics (Mikhail, 2007). The terminology for values generally carry three connotations, namely, attributes, price rates or scores (quantitative), and general measures assigned to something desired and appreciated (axiology) (Najder, 1975) Even though values are viewed as subjective, they can still serve as a standard yardstick to measure human behaviour, determinants for making choices or taking action, as well as the development of character, attitude and behavior. Thus, values may be 
perceived as the seed of community living, whereas attitudes are the trees that exist in various forms and features, and, ethics, sequentially, are the fruits (Hassan, 1994).

Moral values or ethical values are often used interchangeably. The term "ethics" is derived from the Greek ethos and ethikos. Literally, the former means character and the later means moral. Ethic is a branch of philosophy or axiology (the Encyclopedia Americana, 1982: 610). Technically, ethics is concerned with the nature of morality which attempts to define what is "morally good and bad, right and wrong" (The New Encyclopedia Britannica, 1989: 578). According to the encyclopedias:

Ethics, or moral philosophy, is the study of human actions in respect to their being right or wrong (The World Book Encyclopedia, 1993: 339).

Ethics is the branch of philosophy in which men attempt to evaluate and decide upon particular courses of moral action or general theories of conduct. The term "ethics" or "ethic," from the Greek ethikos ("moral") and ethos ("character"), also refers to the values or rules of conduct held by a group or individual, as for example, in the phrases "Christian ethics" or "unethical behaviour (The Encyclopedia Americana, 1982: 610)

Ethics, also called MORAL PHILOSOPHY, the discipline concerned with what is morally good and bad, right and wrong. The term is also applied to any system or theory of moral values or principles (The New Encyclopedia Britannica, 1989: 578).

Having described briefly the meanings of ethics, therefore, ethics can be summarised as the philosophical study which attempts to rationally and systematically define and investigate what is morally right and wrong, good and bad in human behaviour. Because ethics concerns with the philosophical thinking of morality, it is also known as moral philosophy. It examines and analyses general aspects of human behaviour and delineates the theoretical principles of moral conduct (Rahman, 2010: 2).

The term which is often used interchangeably with ethics is "morality." The term "morality" is derived from the Latin mores (sing. mos), which literally means character or custom and habit (Becker and Charlotte, 2001: 485). Morality is regarded as the system of conduct which governs human affairs and relations between individuals (Jones, 2005: 6177-6178) Although ethics and morality are often used interchangeably, both still can be distinguished. For instance, in The World Book Encyclopedia:

The terms 'ethics' and 'morals' are often used interchangeably. Yet philosophers find it convenient to distinguish between the two. Ethics refers to the systematic general science of right and wrong conduct. Morals, or morality, refer to the actual patterns of conduct and the direct working rules of moral action (The World Book Encyclopedia, 1993: 339)

Whereas in the Encyclopedia of World Religions:

The line between ethics and a related term, morality, is fuzzy. But today "ethics" is usually taken to refer to the philosophical and religious study of right behaviour, to the ideals of society, of certain professions, and of individuals in a public context, while "morals" refers more to a personal code of conduct (Ellwood and Alles, 1998: 112). 
Based on the above statements, it can be concluded that ethics refers to the theoretical aspect of morality whereas, morality refers to the actual practical aspects of morality. Ethics therefore is concerned with the theoretical discussion of right and wrong conduct whereas morality is associated with the actual and practical code of conduct While ethics looks at human actions universally, morality looks at them specifically (Yaqub, 1985: 14).

Considering the nature and role of these values, the question whether moral values can be universal is that these elements are already present in human cognition called moral faculty, which is like the language element (language faculty). Thus, Mikhail (2007) tried to prove the existence of moral faculty through the Universal Moral Grammar (UMG) theory, comparable to what Chomsky (1980) did, within a linguistic framework, through his Universal Grammar theory (UG). The UMG theory looks at human cognitive in evaluating a particular matter or action morally in two ways, namely: permissible and impermissible, which is the same way UG looks at the system of language competencies or language faculty that can naturally produce and evaluate the use of that language as either grammatical or ungrammatical.

Basically, the universality of moral values was first identified by Kinnier and his colleagues (2000) in his article entitled, "A Short of Universal Moral Values". This research used text references from the main religions of the world (Smith, 1994) namely Islam, Judaism, Christianity, Confucianism, Taoism and Buddhism, as well as documents from secular organisations such as American Humanist Association, and the United Nations. Even though this research can argue the existence of universal moral values (Universal Moral Value: UMV), the question of UMV concepts used across different countries and socio culture may still be studied.

Thus, this research will try to unravel the true concept of UMV in most countries of the world. Next, the research will identify the components of moral values that are universal together with its concept and practical meaning. This research will also show how moral values can be expressed in language structures or elements involving the two types of language structures in human languages. First, sound that combined into meaningful words and part of words, known as morphemes. Linguists called it as "phonology". Phonology cover intonation and rhythm, as well as the way specific sounds can be combined (Nunes et al., 2006; Searle, 2014). Second, words or morphemes are combined into phrases. Linguists called it as "syntax". It involved in carrying out a structural analysis of language, whether spoken, written or signed (Searle, 2014).

The exploration of UMV in language structures is significant because the results of the study can be applied to language pedagogy that touches on the field of human development, the environment, social issues, health, science and technology (Ali, 2017; Ahmad et al., 1981; Othman, 2014; Zuliana, 2017). In addition, instilling moral values is the main agenda in nation building, education, and drafting and implementing curriculum (Rashid, 2001).

\section{Methodology}

This study uses the qualitative approach that includes systematic texts analysis of articles relating to universal moral values obtained from online databases. The online databases used in this study are Scopus, WoS, Ebscohost, Google Scholar, Proquest and Research Gate. Articles written about moral values from various countries, religions and sociocultural background are gathered through these online data bases.

Four levels of content analysis are used in the process of data extraction namely condensation, code, category and theme (Erlingsson et al., 2017) 
INTERNATIONAL JOURNAL OF ACADEMIC RESEARCH IN BUSINESS AND SOCIAL SCIENCES Vol. 10, No. 7, July, 2020, E-ISSN: 2222-6990 @ 2020 HRMARS

Table 1: The Stages and Adaptation of Content Analysis

\begin{tabular}{|c|c|c|}
\hline Phase & Operational Definition & Application and Adaptation \\
\hline 1. Condensation & $\begin{array}{l}\text { Process of shortening the text while } \\
\text { still preserving the core meaning. }\end{array}$ & $\begin{array}{l}\text { Identifying text statements in } \\
\text { articles that refer to moral values or } \\
\text { universal moral values as well as its } \\
\text { relationship to the language } \\
\text { structure. }\end{array}$ \\
\hline 2. Code & $\begin{array}{l}\text { A code can be thought of as a label; } \\
\text { a name that most exactly describes } \\
\text { what this condensed meaning unit } \\
\text { is about Usually one or two words } \\
\text { long }\end{array}$ & $\begin{array}{l}\text { Labelling of components that } \\
\text { express the universal values from } \\
\text { various countries, religion and } \\
\text { sociocultural background. }\end{array}$ \\
\hline 3. Category & $\begin{array}{l}\text { A category is formed by grouping } \\
\text { together those codes that are } \\
\text { related to each other through their } \\
\text { content or context. }\end{array}$ & $\begin{array}{l}\text { Categorization of the universal } \\
\text { moral values components that have } \\
\text { been labelled into several main } \\
\text { clusters. This process will recognise } \\
\text { the similarities and differences in } \\
\text { terms of concept, component and } \\
\text { meaning. }\end{array}$ \\
\hline 4. Theme & $\begin{array}{l}\text { A theme is expressing an underlying } \\
\text { meaning or expressing data on an } \\
\text { interpretative (latent) level. A } \\
\text { theme answers questions such as } \\
\text { why, how, in what way, or by what } \\
\text { means? }\end{array}$ & $\begin{array}{l}\text { Creating themes based on the } \\
\text { relationship between the } \\
\text { components of the universal moral } \\
\text { values in a cluster. Then, the } \\
\text { process of how it can be matched } \\
\text { with the language structure of the } \\
\text { Al-Quran. }\end{array}$ \\
\hline
\end{tabular}

\section{Result and Discussion}

\section{Universal Moral Values; Meaning and Concept}

The findings of the study found that the concept of moral values and universal moral values have both similarities and differences. The similarities can be seen from the aspect of good values that involve the behaviour, attitude and manner of an individual and their relationship with humans, nature and god (Noordin, 1988). These good values, of course, have distinct entities and numbers between a religion or belief that shape the concept of the values. Nevertheless. these universal moral values can be attained when they are practiced and shared by society from various religion, tradition, culture and country (Balakrishnan, 2010).

As regards religious moral or ethical values, we can find great commonalities that have been shared together by various religions on this world. Moral values (morality or ethics) are indeed among the fundamental essences of all religions. According to The Encyclopedia of World Religions, ethics in a religious perspective is "right behaviour in the light of religion" (Ellwood and Alles, 1998). This means that religious ethics refers to ethical or moral system defined by religion. Thus, the principle of good and bad, of right and wrong conduct or of virtue and vice, in religious ethics, is determined by religion (Rahman, 2010: 5). In brief, it is religion that defines what is morally right and or wrong good and bad. 
All religions have their own codes of ethics or moral systems which delineate universal moral values for their followers, which quite similar and applicable to all humanity. These religious moral values are meant to cultivate in humankind virtue and good character in the light of religion For example, all religions agree that love, forgiveness patience, respect, care for others, merciful, truthfulness, and generosity are good and need to be cultivated and that theft, slandering, killing, hatred, enmity and exploitation are bad and need to be avoided (Rahman, 2010: 5-6).

This shows that the concept of UMW as stated by Kinnier et al (2000) can be defined as a principle of decent, ideal and holy, socially and personally expressed and adopted by common people, regardless of their culture, ethnicity, gender, religion, nationality or any other distinctive attribute (Kinnier et al., 2000).

\section{Clusters of UMV}

There are seven countries that have highlighted the universal properties of moral values, namely Malaysia, Turkey, New Zealand, Australia, The United States of America (USA), United Kingdom and Japan (Tan, 1997; Karasel et al., 2018). Malaysia has 16 universal moral values based on four religions, and ethnic groups namely Malays (Islam), Chinese (Buddhism and Taoism), Indian (Hinduism) dan Christians. The 16 moral values are compassion, self-reliance, humility, respect, love, justice, freedom, courage, physical and mental cleanliness, honesty, diligence, cooperation, moderation, gratitude, rationality and public-spiritedness. These 16 moral values have also become the focus of the moral education curriculum and has been indirectly absorbed into almost all the subjects in school (Tan, 1997).

Besides that, the UMV concept has also been administered into the education curriculum of six countries. Turkey listed 20 values which are justice, independence, peace, being scientific, diligence, solidarity, sensitivity, honesty, equality, tolerance, freedom, respect, love, hospitality, responsibility, hygiene, patriotism, health, family bounds and helpful. New Zealand identified 8 values: honesty, obeying, caring for others, respect, responsibility, good-will, mercy and duty as the values of the country. Australia stated 9 values namely objectivity, respect to reality, respect to opinions, justice, equality, caring for others, freedom, accept diversities, seeking peaceful solutions to clashes. Then, United Stated of America had 12 values specified freedom, secrecy, trueness, power of justice, human dignity, justice, loyalty, international human rights fairness, equality, responsibility, honesty, diversity respect to authority as the values of the country. Following them is United Kingdom which listed 8 values: justice, honesty, trust, self-respect, responsibility, fairness, humaneness and respect to differences. Lastly, Japan discovered 13 values: justice, respect to the community, nature, the elderly and parents, being industrious, courageous, sincere, freedom, organisation, kindness, courtesy, friendship, modesty, patriotism and respect to other cultures (Karasel et al., 2018).

Out of all the 86 moral values discussed, some were mentioned in almost all the countries such as justice, freedom and honesty. Some of the moral values have the same or almost the same meaning but used different terminologies such as love/caring, for others/humaneness/kindness and modesty/moderation. Therefore, this study found that these values can be updated and placed into four main clusters, and each cluster has components of values that illustrate the UMV cluster concept. This study recognises that the UMV distribution by Kinnier et al. (2000) is able to illustrate the diversity of these values in a more structured and comprehensive manner as they embody the universal moral values of the individual with God and a higher order, the moral values of the individua, the moral values of the individual with other people, values of the individual with the 
INTERNATIONAL JOURNAL OF ACADEMIC RESEARCH IN BUSINESS AND SOCIAL SCIENCES Vol. 10, No. 7, July, 2020, E-ISSN: 2222-6990 @ 2020 HRMARS

environment. Through this cluster as well, the similarities and differences between the 86 moral values found in each country may be identified in terms of concept, component and meaning.

The four clusters are:

(1) Commitment to something greater than oneself, to recognize the existence of and be committed to a supreme being, higher principle, transcendent purpose or meaning to one's existence.

(2) Self-respect, but with humility, self-discipline, and acceptance of personal responsibility

(3) Respect and caring for others.

(4) Caring for other living things and the environment

First Cluster of UMV and Its Component: Commitment to Something Greater than Oneself The first UMV cluster is the individual commitment to find and obey something that are more important than oneself. That includes The Almighty, legal principles and actual goals in life. Based on the analysis, five components of universal moral values illustrate the concept of the first cluster which are: justice, fairness, freedom, equality and obeying. Justice carries the meaning of fair treatment towards everybody (Zhar et al., 2003; Kertas Kerja Kajian Sistem Pendidikan Kebangsaan; Cicek etal. 2012; Lepage et al., 2011; Ikemoto, 1996), whereas fairness means treating people fairly and not biased (Fadhilah, 2012). Both the components have the same concept of equality that are not biased and with fair treatment to all without any discrimination in order to protect the common good where everyone is subject to the same laws and treatment socially and economically. These moral values are conveyed in countries such as Australia, Malaysia, the United States of America, Turkey, United Kingdom and Japan (Zbar et al., 2003; Kertas Kerja Kajian Sistem Pendidikan Kebangsaan; Cicek et al., 2012; Lepage et al., 2011; Fadhilah, 2012; Ikemoto, 1996).

While, three components which are freedom, equality and obeying are different in terms of concept and meaning. Freedom is the balance between rights, responsibilities and citizenship privileges that are free from any conflict or restriction. However, this freedom is subject to the rules and laws established by religion, society and country (Kertas Kerja Kajian Sistem Pendidikan Kebangsaan; Zbar et al., 2003).

While equality refers to the treatment of all citizens equitably without any hierarchical class prescribed by law. Obeying, on the other hand, is compliance to God-given-rules and laws. These components have been endorsed in several countries such as: freedom in Malaysia and Australia (Kertas Kerja Kajian Sistem Pendidikan Kebangsaan; Zbar et al., 2003), equality in USA and Turkey (Cicek et.al, 2012; Kafadar et al., 2018), and obeying is applied in New Zealand (Regan, 19900.

\section{Second Cluster of UMV and Its Component: Self-Respect, Self-Discipline, and Acceptance of Personal Responsibility}

In addition, the second UMV involves internal moral values that is built into one's cognitive mind in relation to the self. The concept explains the ability of an individual to understand, recognise and shape his/her personal self. Components such as freedom, honesty, self-reliance, courage, mental cleanliness, diligence, moderation, rational, sincerity, hygiene, health, peace, seeking peaceful solutions to clashes, responsibility, sensitiveness, secrecy, objectivity, trust, trueness, independence, self-respect describe the concept of the second cluster.

From the list of components of values, hygiene and health are similar in terms of concepts and meanings that relate to any form of individual health care as the means of prevention from catching any diseases. Only Turkey stated this as a value (Kafadar et al., 2018). This health aspect also includes 
internal health that is known as mental cleanliness. These components include pureness of heart, healthy and constructive thinking, polite and truthful speech and behaviour or better known as trueness. (Kertas Kerja Kajian Sistem Pendidikan Kebangsaan; Tay, 2013).

In relation to the freedom component, a difference can be seen with freedom in the first cluster and the second cluster in terms of concept where freedom relates to the self in the latter. This component explains one's desire to speak, act and think without any boundaries. Countries such as USA, Japan and Turki practise this component (Cicek et al., 2012; Ikemoto, 1996; Kafadar et al., 2018). However, the component of personal freedom can be balanced with the component of responsibility. This component carries with it the idea that the individual's freedom of thought, speech and action should be accompanied by a sense of responsibility and duty for the consequences (Ersoy et al., 2012; Keown et al., 2018; Anam et al., 2019). This in found in four countries namely Turkey, New Zealand, USA and UK (Ersoy et al., 2012; Keown et al., 2005; Kafadar et al., 2018). The same concept also applies to the component of courage that needs to go hand in hand with the component of responsibility, which means that reckless acts are not considered courage. Courage is basically the willingness of an individual to face whatever situation and challenges with resilience (Kertas Kerja Kajian Sistem Pendidikan Kebangsaan; Ikemoto, 1996). This component is stated in Malaysia and Japan (Kertas Kerja Kajian Sistem Pendidikan Kebangsaan, Ikemoto, 1996).

Next, the components of self-reliance and independence also have the same meaning and concept which is the ability of an individual to do something without depending on others for assistance. This component is stated in 2 countries: Malaysia and Turkey (Kertas Kerja Kajian Sistem Pendidikan Kebangsaan, Kadafar et al., 2018) Even so, individuals cannot achieve these components unless they have attained the component of self-respect in themselves, or in other words, having confidence in their own abilities (Ferkany, 2006). Another component is gratitude that carries the meaning of being thankful and appreciative for everything that we possess and expressing it sincerely.

Other components that have their own meanings and concepts are honesty which relates to the genuine and sincere attitude and behaviour of an individual who can be trusted to do a task without expecting anything in return. Among the countries that had set guidelines for this concept are Malaysia, Turkey, New Zealand, USA and UK (Kertas Kerja Sistem Pendidikan Kebangsaan, Lepage et al., 2011; Keown et al., 2005; Kafadar et al., 2018; Anam et al., 2019). This component is perceived to be related to the component of sincerity because being honest is a genuine feeling that comes straightr from the heart of the individual who is sincere and who is not just putting on an act. Consequently, the values of sincerity and honesty resulted in the moral value component of diligence, objectivity, trust and trueness in one's action.

Diligence refers to the individual's continuous efforts to complete a task with perseverance, persistence and determination. Whereas, rational is the ability of the individual who is able to take appropriate action through reasoning based on tangible rationale and evidence (Kertas Kerja Kajian Sistem Pendidikan Kebangsaan). Therefore, the objectivity component refers to an individual who is not easily influenced as the individual is guided by his/her principles to complete a task. Trust refers to the attitude of individuals who have firm beliefs in the reliability of a person (Zbar et al., 2003; Smyth et al., 2010). Besides that, the actions or decisions taken are also done in moderation which means the attitude towards deciding or taking action is moderate and not in extreme (Kertas Kerja Kajian Sistem Pendidikan Kebangsaan, Ikemoto, 1996). Moderation does not mean simply doing something at will but, in fact, an individual need to possess the value of being scientific which emphasizes on full concentration when thinking about a problem that need to be solved and backed 
INTERNATIONAL JOURNAL OF ACADEMIC RESEARCH IN BUSINESS AND SOCIAL SCIENCES

Vol. 10, No. 7, July, 2020, E-ISSN: 2222-6990 @ 2020 HRMARS

by evidence (Merey et al., 2012). All three components are especially mentioned in Turkey (Merey et al., 2012).

\section{Third Cluster Of UMV and Its Component: Respect and Caring for Others}

The third UMV cluster involves universal moral values related the relationships between one person and another. It fundamentally arises from feelings of respect and love for others (Kinnier et al., 2000). Thus, among the components of universal moral values that can be categorized in this cluster are: respect, respect to the community, respect to other cultures, diversity respect to authority, accepting diversities, caring others, kindness, compassion, good-will, humaneness, tolerance, humility, love, cooperation, public-spiritedness, courtesy, friendship, elderly, parents, family bounds, being industrious, organization, patriotism, loyalty, diligence solidarity, mercy, duty, human dignity, helpful, hospitality, being scientific, gratitude.

From the components above, the components of respect, respect to the community, respect to other cultures, diversity respect to authority and accepting diversities are perceived as having the same conceptual meaning of accepting and respecting others or communities of different culture, ethnic background, race and religion. These values are stressed upon especially in Australia, New Zealand, Malaysia, Turkey, United Kingdom and the United States of America (Zbar et al., 2003; Keown et al., 2005; Kertas Kerja Kajian Sistem Pendidikan Kebangsaan; Ikemoto, 1996; Kafadar et al., 2018; Anam et al., 2019; Cicek et al. 2012). While other components of UMV that share the same conceptual meaning of caring, concern and considerate towards other people's situation are kindness, compassion, good-will and humaneness. These values, expressed in Australia, New Zealand, Malaysia, UK, and Japan, explains the attitude of concern towards rights, self-worth and situations faced by others (Zbar et al., 2003; Keown et al., 2005; Kertas Kerja Kajian Sistem Pendidikan Kebangsaan; Eileen et al., 1975; Ikemoto, 1996). These values run parallel to three value components namely mercy, hospitality and helpful. This is because mercy involves feelings of sympathy towards others (Extraordinary Jubilee of Mercy); hospitality, on the other hand, is the friendly and generous entertainment of guests, visitors or strangers (Merey et al., 2012); while helpful is a desire to be helpful and willing to assist others (Merey et al., 2012)

Next, the components of friendship, elderly, parents and family bounds have similar conceptual meaning in terms of keeping good relationships and ties between individuals and members of their family such as their parents, friends and elderly. Japan and Turkey set guidelines for these components with connotations of understanding, trusting and helping one another. This is supported by the value component of loyalty that refers to loyalty in relationships with other people such as loyalty to friends (Kafadar et al., 2018). This good relationship may be strengthened with other universal value components even though they have slightly different conceptual meanings. Humility refers to the attributes of a person who is virtuous in his behaviour towards others (Kertas Kerja Kajian System Pendidikan Kebangsaan), which includes the courtesy component in conversation and actions (Ikemoto, 1996). This is followed by the tolerance component that explains individual values capable of compromise, patience and self-control to avoid confrontations and misunderstanding with others (Ersoy et al., 2012). This is also connected to the components of peace and seeking peaceful solutions to clashes, or in other words, constantly seeking peace or contentment within oneself in the interest of peace in the event of a conflict (Kafadar et al.; Zbar et al., 2003). This value is only stated in Turkey and Australia (Kafadar et al., 2018; Zbar et al., 2003) 
Being considerate towards people around us can be manifested through the value component of sensitiveness, love and secrecy. Sensitiveness is a feeling of positive emotional and physical response within oneself towards what is happening (Kafadar et al., 2018), that involves the component of love which is a deep sense of caring for someone without any personal interest attached to it (Kertas Kerja Kajian Sistem Pendidikan Kebangsaan). Even though the level of sensitivity and the sense of caring for the other person is high, it can be balanced with the secrecy value component of an individual's personality that preserves confidentiality without humiliating others (Bradley, 2013). These concepts can also be combined with the value component of public spiritedness and cooperation. Publicspiritedness refer to the willingness to work together to complete a task for the common good in order to create harmony in society (Kertas Kerja Kajian Sistem Pendidikan Kebangsaan). While cooperation, on the other hand, is a joint effort to achieve a goal (Kertas Kerja Kajian Sistem Pendidikan Kebangsaan).

The universal moral value that involves relationships between individuals in the context of their career and country is being industrious where one has to understand the importance of working and being willing to work with diligence solidarity, that is hardworking, in an industry (Ikemoto, 1996; Katilmis, 2017). This happens after a person has attained the value of duty which is understanding the tasks and duties that need to be performed to the best of his/her ability. In order to guarantee the quality of teamwork, an individual need to possess the value component of organisation which has the conceptual meaning of cooperating with one another towards achieving the objectives of a company or organisation (Ikemoto, 1996). Whereas, in the context of nationality, a person needs to have the value component of patriotism which means feelings of love and pride for one's country (Ersoy et al., 2012; Ikemoto, 1996).

\section{Fourth Cluster of UMV and Its Component: Caring for Other Living Things and The Environment}

The fourth cluster of UMV is related to the relationship between individuals with other living things as well as nature. This concept emphasizes on the importance of preserving and conserving flora and fauna. Examples of this concept are not harming or killing animals, and not destroying the environment either on land, water or air. The two components that may be categorised under this cluster are physical cleanliness and nature. Physical cleanliness means taking care of the cleanliness of the environment and the ecosystem, besides one's own personal hygiene (Kerta Kerja Kajian Sistem Pendidikan Kebangsaan), whereas the value component of nature refers to the care and love one feels for the environment, plants and animals. This value is recorded in two countries namely Malaysia and Japan (Kertas Kerja Kajian Sistem Pendidikan Kebangsaan; Ikemoto, 1996). 
INTERNATIONAL JOURNAL OF ACADEMIC RESEARCH IN BUSINESS AND SOCIAL SCIENCES Vol. 10, No. 7, July, 2020, E-ISSN: 2222-6990 @ 2020 HRMARS

All the components and clusters discussed above is summarized in the diagram below:

Diagram 1: Clusters and Components of Universal Moral Values

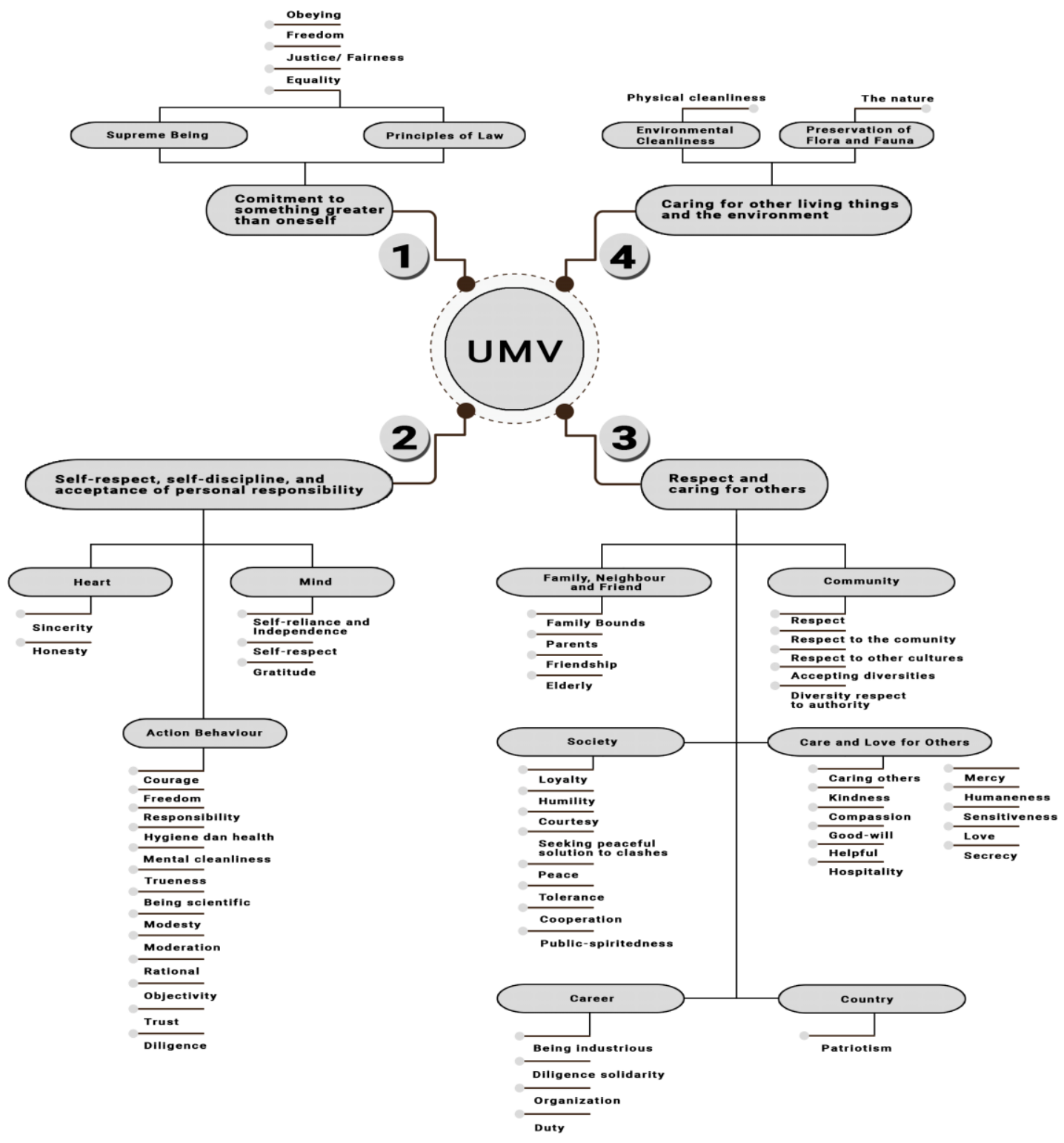

\section{Application of UMV In Language Structure: Arabic Parts of Speech Analysis as A Model}

In order to prove the application of UMV in language structures, this study uses the analysis of Arabic word classes as a model. In traditional Arab grammar, words are divided into three namely nouns, verbs and particles. Upon observation, it can be seen that the choice of language usage for each of these types of words among scholars of Arabic grammar such as Sibaiwah (1988), Al-Mubarrid (N.D), IbnSarraj (N.D) is based on examples that they create themselves and their selection is random as long as it describes the word class For example, Sibawayh (1988) substantiated the use of noun with ragul (man), faras (horse) and hāiț (wall).

Therefore, this study finds that the selection of arguments should be based on the source language such as the Quran and be able to match with the elements of universal moral values. This can be 
INTERNATIONAL JOURNAL OF ACADEMIC RESEARCH IN BUSINESS AND SOCIAL SCIENCES

Vol. 10, No. 7, July, 2020, E-ISSN: 2222-6990 @ 2020 HRMARS

realised by searching for sentence structures or words that convey the message of any UMV component either explicitly or implicitly, and then analysing the syntax. To illustrate the four UMV clusters in the language structure, four Qur'anic verses were purposively selected;

The first cluster (the obeying component):

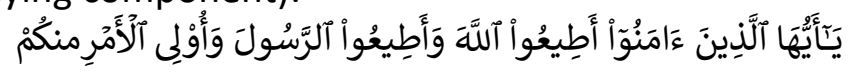

Meaning: Believers! Obey Allah and obey the Messenger, and those from among you who are invested with authority. (Al-Nisa' 59)

The second cluster (objectivity component):

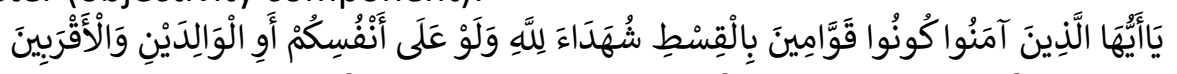

Meaning: Believers! Be upholders of justice, and bearers of witness to truth for the sake of Allah, even though it may either be against yourselves or against your parents and kinsmen. (Al-Nisa': 135)

The third cluster (being scientific component):

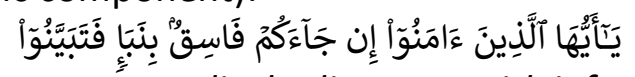

Meaning: Believers, if there comes to you a disobedient one with information, investigate. (Al-Hujurat: 6)

The fourth cluster (nature/environment protection component):

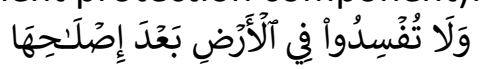

Meaning: And do not cause corruption upon the earth after its reformation. (Al-A'raaf: 56)

\begin{tabular}{|c|c|c|c|c|}
\hline $\begin{array}{l}\text { Arabic Part of } \\
\text { Speech } \\
\text { UMV Cluster }\end{array}$ & $\begin{array}{c}\text { Cluster } 1 \\
\text { (Obeying) }\end{array}$ & $\begin{array}{c}\text { Cluster } 2 \\
\text { (Objectivity) }\end{array}$ & $\begin{array}{c}\text { Cluster 3 } \\
\text { (Being } \\
\text { Scientific) }\end{array}$ & $\begin{array}{c}\text { Cluster } 4 \\
\text { (Environment } \\
\text { Protection) }\end{array}$ \\
\hline 1) Noun (الاسم) & 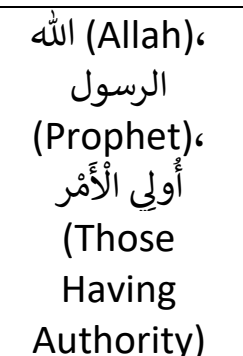 & $\begin{array}{c}\text { قََََوامِينَ } \\
\text { (custodians) } \\
\text { القسط ( } \\
\text { (justictice) }\end{array}$ & $\begin{array}{c}\text { فَاسِقُ (a wicked } \\
\text { person) } \\
\text { نَبَأ (information) }\end{array}$ & 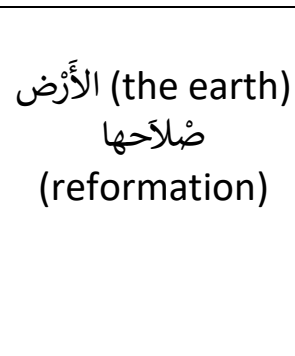 \\
\hline 2) Verb (الفعل) & أُطِيُعُوا (Obey) & كُونُوا (Be) & $\begin{array}{c}\text { تَبَيَنُوا (investigate) } \\
\text { (intes }\end{array}$ & $\begin{array}{c}\text { الا تُفْسِدُوا ((Do } \\
\text { not cause } \\
\text { corruption) }\end{array}$ \\
\hline 3) Participle (الحرف) & 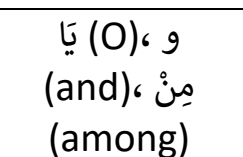 & $\begin{array}{c}\text { (against) } \\
\text { (to)، عللام }\end{array}$ & إِن (if)، بـ (with) & 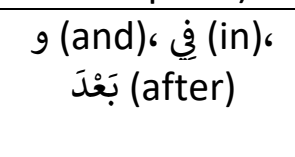 \\
\hline
\end{tabular}

Then, the sentence structures of the Qur'anic verses above are syntactically analysed within the framework of the four main UMV clusters in the following table:

Table 2: Syntactic Analysis of Arabic Part of Speech in the light of Universal Moral Values

Table 2 above shows that the language choices used to explain the structure and type of the words can be done for a purpose and sourced from materials such as the Quran in the Arab language context. The structure may not only be analysed syntactically in linguistic terms but also may be 
matched to the elements of universal moral values. For example, the first UMV cluster that touched on the value of obedience to a power higher than personal interests such as obedience to the commandments of God (Allah), Prophet and Authorities can be expressed through the verb أطِيُوا (obey), nouns (Allah), Prophet and Authorities, and the participle that connects the verbs and the nouns. This gives an impression that the universal moral values can be identified through key words

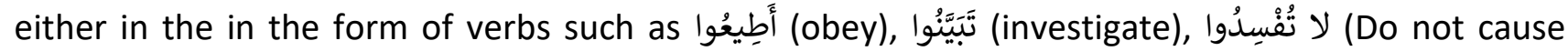
corruption) or nouns such as القِسْط (justice), in addition to understanding the context of the verse. This also proves that even though the verses are aimed at Muslims, it still contains the core universal moral values which are upheld by various religions and socio-culture of the world as described earlier in relation to the UMV concept and its components.

\section{The Concept of the Qur'an as Hudan Wa Rahmatan Lil Alamin}

The Qur'an is universal and was brought down for all humanity, for Muslims and Non-Muslims alike, as guidance towards achieving moral values. This matter is stated clearly in the Qur'an from these words which is: "The month of Ramadhan [is that] in which was revealed the Qur'an, a guidance for the people and clear proofs of guidance and criterion" (Al-Baqarah: 185). Thus, the concept of the values can be explained further using the key words as follows:

\section{Verb أَطِيُعُوا (obey)}

Verbs أَطِيُعْوا originate from three letters (ط و ع). There are 129 repetitions in the Qur'an with different patterns of words. According to Raghib al-Asfahani (2017,2: 611) in al-Mufradat fi Gharib al-Quran, the meaning of $(b, b)$ is subservient, obey and the opposite is coercion. Most of the sentences in the Qur'an are in the imperative form. This means that a compliance is enforced upon an order. In the context of the Qur'an, compliance is in accordance with the hierarchy that Allah SWT has established. According to al-Sabuuniy (1980), the first compliance is to Allah SWT, then the apostles by adhering to the Qur'an and the Sunnah. After that comes compliance to trustworthy leaders who follow the Islamic law. In the event of a dispute, the crux of the issue can be resolved by turning to the Qur'an and Sunnah for guidance.

\section{Verb تَبَيَّنُوا (investigate)}

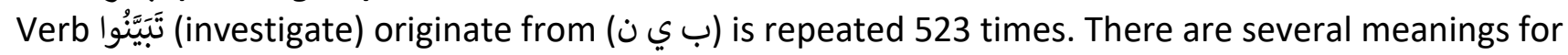
the word (ب ي ن ) among them are understandable, clear, clear evidence, describing things that are either common knowledge or obscure (al-Asfahani, 2017; 1: 248-288) It also means everything that comes with it, the truth is discovered through proof and witness testimony. In the context of sentence 6 surah al-Hujurat above, it means asking for clarification and investigating the news before making a decision in order to avoid regret and injustice. Seeking explanations and evidence can prevent misunderstandings, conflicts and the like from happening. This is because people who are used to doing evil will also also be used to telling lies (Al-Maraghi, 1964; 26: 126).

\section{Verb لا تُفْسِدُوا (Do not cause corruption)}

The verb لا تُفْسِدُوا لـ (Do not cause corruption) is repeated 50 times in the Qur'an with different word patterns The root word of this verb consists of three alphabets which are (ف س د) and it means damage as well as moving out of the normal line either by a little or a lot. The antonyms for this verb are (الصلاح) advantages and benefits. The verb (ف س د) is used to refer to damage to the soul, physique 
INTERNATIONAL JOURNAL OF ACADEMIC RESEARCH IN BUSINESS AND SOCIAL SCIENCES Vol. 10, No. 7, July, 2020, E-ISSN: 2222-6990 @ 2020 HRMARS

and mental faculties (al-Asfahani, 2017; 3: 62) According to al-Qurtubiy (1964), (ف س د) means exiting from a straight path and opposing it. In the context of the sentence (Al-A'raaf: 56), Allah SWT forbids us (humans) from causing destruction either big or small. Also included in the damage category are water wastage, cutting down trees bearing lots of fruits \{al-Qurtubiy (1964)\} and greater damages such as committing shirk as well as performing immoral or evil deeds even after Allah Almighty has established all His laws through his messengers (Al-Sabuuniy, 1980).

\section{Nouns القِسنط (justice)}

The words of Allah (ق س طa) (ق) 25 times in the Qur'an, means fair. In the context of the verse (Al-Nisa': 135), القِسنط (justice) means Allah Almighty ordered mankind to remain committed to justice and fairness to their relatives, other people and even to themselves (Al-Sabuuniy; 1980, 1: 285; Al-Tabari, N.D, 9: 302).

Conclusion

Overall, universal moral values in the life of mankind can be identified through shared basic principles or common beliefs that transcend across all religions, socioculture and country. It originated from the human cognitive system which is the Universal Moral Grammar that distinguishes things that are permissible and impermissible or good and bad. Hence, it can be expressed through the syntactic structure of a language that involves the combination of several words to form a sentence that can convey UMV messages. This can be proven by analysing some Qur'anic verses syntactically and semantically within the framework of UMV that has 86 value components under four main clusters which are as follows; 1) A commitment to obey a higher entity than one's personal gain, 2) selfrespect with humility, self-discipline, and acceptance of personal responsibility, 3) respect and caring for others, and 4) caring for other living things and the environment.

\section{Acknowledgement}

This study was supported by the Ministry of Education Malaysia under Fundamental Research Grant Scheme for Research Acculturation of Early Career (FRGS-RACER), KPM entitled Model Baharu Kurikulum Nahu Arab-Quran Bagi Penerapan Nilai Murni Sejagat, (Research Code: RACER/1/2019/SSI01/USIM//1).

\section{Corresponding Author}

Mohd Nizwan Musling, Universiti Sains Islam Malaysia, Malaysia, mohdnizwan@usim.edu.my, Fakulti Pengajian Bahasa Utama, Universiti Sains Islam Malaysia, Bandar Baru Nilai, 71800 Nilai, Negeri Sembilan.

\section{References}

Ahmad, I., \& Din, H. (1981). Nilai-nilai murni dalam bahan pengajaran bahasa melayu intensif kepada pelajar asing: kes Universiti Utara Malaysia, Nilai Kesopanan yang Semakin Diabaikan. Dewan Budaya. Ogos. 1-25.

Al-Asfahani, R. (2017). al-Mufradat fi Gharib al-Quran. Translated by Ahmad Zaini Dahlan. Jawa Barat: Pustaka Khazanah Fawa'id.

Ali, H. M. M. (2017). Inculcating universal values via English language education. Journal of Education and Social Sciences, 6(2), 169-174. https://doi.org/ISSN 2289-1552 
INTERNATIONAL JOURNAL OF ACADEMIC RESEARCH IN BUSINESS AND SOCIAL SCIENCES

Vol. 10, No. 7, July, 2020, E-ISSN: 2222-6990 @ 2020 HRMARS

Al-Maraghi, Mustafa, A. Bin. (1946). Tafsir al-Maraghi. Mesir: Syirkat Maktabah wa Matba'ah alBabiy al-Halabiy wa Awladuhu.

Al-Mubarrid. (N.D). Al-Muqtadhab. Beirut: 'Alamulkutub.

Al-Qurtubiy, S. (1964). Al-Jami' li Ahkam al-Quran. Al-Kaherah: Dar al-Kutub al-Misriyyah.

Al-Sabuuniy, A. (1980). Sofwat al-Tafasir. Beirut: Dar al-Qalam.

Anam, S. D., Murtadho, N., \& Kuswandi, D. (2019). The moral education and internalization of humanitarian values in pesantren. Journal for the Education of Gifted Young Scientists, 7(4), 815-834. https://doi.org/10.17478/jegys.629726

Balakrishnan, V. (2010). The development of moral education in Malaysia. Asia Pacific Journal of Educators and Education, 25, 89-101.

Becker, L. C., \& Charlotte, D. B. (2001). Encyclopedia of Ethics. Vol. 1. "Ethics and Morality".

Bradley, L. (2013). Keeping it Secret: The morality of confidentiality. Retrieved Mei, 2,2020 from https://www.academia.edu/4089284/Keeping_it_Secret_The_Morality_of_Confidentiality

Chomsky, N. (1976). Reflections on language. London: Temple Smith.

Cicek, V., Ulker, R., \& Tarman, B. (2012). Comparison of character education in US and Turkish educational systems: Globalizing American education system. Energy Education Science and Technology Part B: Social and Educational Studies, 4(3), 1311-1322.

Eileen, S. W., \& Westerlund, S. R. (1975). Humane Education: An Overview. United States: The National Association for The Advancement of Human Education.

Ellwood, R. S., \& Alles, G. D. (1998). The Encyclopedia of World Religions. New York: Facts on File.

Erlingsson, C., \& Brysiewicz, P. (2017). A hands-on guide to doing content analysis. African Journal of Emergency Medicine, 7, 93-99. https://doi.org/10.1016/j.afjem.2017.08.001

Ersoy, F., \& Şahin, T. (2012). Examination of social studies textbooks in terms of approaches of values education. Kuram ve Uygulamada Egitim Bilimleri, 12(2), 1547-1558.

Fadhilah. (2012). Refleksi terhadap makna keadilan sebagai fairness menurut John Rawls dalam perspektif keindonesiaan. Jurnal Kybernan, 3(1), 25-37.

Ferkany, M. A. (2006). The nature and importance of self-respect. Retrieved Mei, 1, 2020 from https://www.academia.edu/1914969/The_nature_and_importance_of_self-respect

Givón, T. (2001). Syntax: An Introduction. Philadelphia: John Benjamins Publishing Company.

Godlewski, R. (2015). Definition of duty and freedom with conflict. Review of Contemporary Philosophy, 14, 102-125.

Hassan, M. A. (1994). Citra Karya: falsafah, nilai dan etika dalam perkhidmatan awam. Institut Tadbiran Awam Negara (INTAN): Kuala Lumpur.

IbnSarraj, A. B. M. (N.D). Al-Usul fi Al-Nahw. Beirut: Muassasah Al-Risalah.

Ikemoto, T. (1996). Moral Education in Japan; Implications for American Schools. Unpublished Thesis. Retrieved April, 26, 2020 from http://www.hi-ho.ne.jp/taku77/papers/thes595.htm

Jones, L. (2005). Encyclopedia of Religion. $2^{\text {nd }}$ edition. Vol. 9. "Morality and Religion." Detroit: Macmillan Reference USA.

Kafadar, T., Ozturk, C., \& Katilmis, A. (2018). Comparison of the Social Studies curricula of different countries in terms of values education. Kirsehir Education Faculty, 19(1), 178-200. https://doi.org/10.29299/kefad.2018.19.005

Karasel, N., Altınay, F., Dagli, G., \& Altmay, Z. (2018). An investigation of universal values and disability awareness in course books. Quality \& Quantity, 52, 1235-1244. https://doi.org/10.1007/s11135-018-0693-x 
INTERNATIONAL JOURNAL OF ACADEMIC RESEARCH IN BUSINESS AND SOCIAL SCIENCES

Vol. 10, No. 7, July, 2020, E-ISSN: 2222-6990 @ 2020 HRMARS

Katilmis, A. (2017). Values education as perceived by Social Studies teachers in objective and practice dimensions. Educational Sciences: Theory \& Practice, 17(4), 1231-1254. https://doi.org/10.12738/estp.2017.4.0570

Keown, P., Parker, L., \& Tiakiwai, S. (2005). Values in the New Zealand curriculum. New Zealand: Wilf Malcolm Institute of Educational Research.

Kertas Kerja Kajian Sistem Pendidikan Kebangsaan (MTT 2353). Retrieved Mei, 1, 2020 from https://www.scribd.com/doc/91202794/Kertas-Kerja-Kajian-Sistem-Pendidikan-Kebangsaan

Kinnier, R. T., Kernes, J. L., \& Dautheribes, T. M. (2000). A short list of universal moral values. Counseling and Values, 45(1), 4-16. https://doi.org/10.1002/j.2161-007X.2000.tb00178.x

Lepage, P., Akar, H., Temli, Y., Derya, S., Hasser, N., \& Ivins, I. (2011). Comparing teachers' views on morality and moral education, a comparative study in Turkey and the United States. Teaching and Teacher Education, 27, 366-375. https://doi.org/10.1016/j.tate.2010.09.005

Merey, Z., Kus, Z., \& Karatekin, K. (2012). Comparison of elementary Social Studies curricula of Turkey and the United States on values education. Educational Sciences: Theory \& Practice, 12(2), 1627-1632.

Mikhail, J. (2007). Universal moral grammar: theory, evidence and the future. TRENDS in Cognitive Sciences, 11(4), 143-152. https://doi.org/10.1016/j.tics.2006.12.007

Najder, Z. (1975). Values and Evaluations. Clarendon Press: O.U.P.

Noordin, W. M. Z. M. (1988). Ke arah pelaksanaan nilai-nilai murni di dalam KBSM: Falsafah Pendidikan Negara. Kertas kerja yang dibentangkan dalam Seminar Nilai-Nilai Murni Merentas Kurikulum Dalam KBSM di Universiti Kebangsaan Malaysia, Bangi, Malaysia.

Nunes, T., \& Bryant, P. (2006). Improving literacy by teaching morphemes. New York: Routledge Taylor \& Francis Group.

Othman, M. K. (2014). Hubungan penerapan nilai murni dalam pengajaran bahasa Melayu dengan penghayatan nilai murni pelajar. Journal of Human Development and Communication, 3(Special Issue), 81-92.

Rahman, M. R. A (2010). Introduction to Islamic and Buddhist Personal Ethics. Negeri Sembilan: Universiti Sains Islam Malaysia.

Rashid, A. R. A. (2001). Nilai-nilai murni dalam pendidikan: Menghadapi perubahan dan cabaran alaf baru. Kuala Lumpur: Utusan Publications \& Distributors Sdn. Bhd.

Regan, D. H. (1990). Reasons, Authority, and the meaning of 'Obey': further thoughts on Raz and obedience to law. Canadian Journal of Law and Jurisprudence, 3(1), 3-28.

Saldana, J. (2011). Fundamentals of Qualitative research. New York: Oxford University Press.

Searle, J. R. (2014). The structure and functions of language. Studies in Logic, Grammar and Rhetoric, 36(49), 27-40. https://doi.org/10.2478/slgr-2014-0001

Sibawayh, A. U. (1988). Al-Kitab. Kaherah: Maktabah Al-Khanji.

Smith, H. (1994). The illustrated world's religions. San Francisco: Harper.

Smyth, H., Gustafsson, M., \& Ganskau, E. (2010). The value of trust in project business. International Journal of Project Management, 28, 117-129. https://doi.org/10.1016/j.ijproman.2009.11.007

Tan, S. K. (1997). Moral values \& Science teaching: A Malaysian school curriculum initiative. Science \& Education, 6, 555-572. https://doi.org/10.1023/A:1008613709213 
INTERNATIONAL JOURNAL OF ACADEMIC RESEARCH IN BUSINESS AND SOCIAL SCIENCES

Vol. 10, No. 7, July, 2020, E-ISSN: 2222-6990 @ 2020 HRMARS

Tay, B. (2013). The views of prospective Social Studies and classroom teachers about values and values education. Educational Research and Reviews, 8(9), 560-567. https://doi.org/10.5897/ERR2012.1098

The Encyclopedia Americana (1982). $2^{\text {nd }}$ edition. Vol. 10, "Ethics." Darbury, Conn: Grolier.

The New Encyclopedia Britannica. (1989). 15 th edition. Vol. 4, "Ethics." Chicago: Encyclopedia

The World Book Encyclopedia. (1993). Vol. 6, "Ethics." London: World Book.

Yaqub, H. (1985). Etika Islam: Pembinaan akhlaqulkarimah (Suatu pengantar). Bandung: Diponegoro.

Zbar, M. V., Brown, M. D., Bereznicki, M. B., \& Hooper, D. C. (2003). Values Education Study. In Curriculum Corporation. Retrieved April, 25, 2020 from

http://www.dest.gov.au/NR/rdonlyres/F6BA105C-4167-448B-89A3-

37769A624AF8/4528/VES_Report.pdf

Zuliana, E. (2017). Nilai-nilai karakter dalam pembelajaran bahasa Arab. A Nabighoh Jurnal Pendidikan Dan Pembelajaran Bahasa Arab, 19(1), 127-156.

https://doi.org/https://doi.org/10.32332/an-nabighoh.v19i1.761 